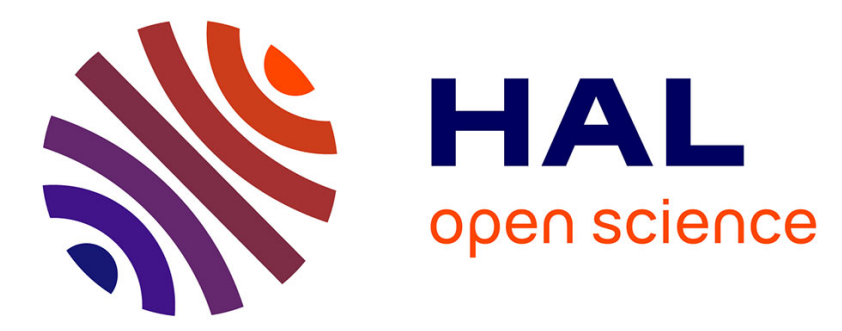

\title{
A mandible of the hyracoid mammal Titanohyrax andrewsi in the collections of the Muséum National d'Histoire Naturelle, Paris (France) with a reassessment of the species
}

Rodolphe Tabuce

\section{To cite this version:}

Rodolphe Tabuce. A mandible of the hyracoid mammal Titanohyrax andrewsi in the collections of the Muséum National d'Histoire Naturelle, Paris (France) with a reassessment of the species. Palaeovertebrata, 2016, 40 (1), pp.e4. 10.18563/pv.40.1.e4 . hal-03100188

\author{
HAL Id: hal-03100188 \\ https://hal.science/hal-03100188
}

Submitted on 21 Jan 2021

HAL is a multi-disciplinary open access archive for the deposit and dissemination of scientific research documents, whether they are published or not. The documents may come from teaching and research institutions in France or abroad, or from public or private research centers.
L'archive ouverte pluridisciplinaire HAL, est destinée au dépôt et à la diffusion de documents scientifiques de niveau recherche, publiés ou non, émanant des établissements d'enseignement et de recherche français ou étrangers, des laboratoires publics ou privés. 


\title{
A mandible of the hyracoid mammal Titanohyrax andrewsi in the collections of the Muséum National d'Histoire Naturelle, Paris (France) with a reassessment of the species
}

\author{
RODOLPHE TABUCE \\ Institut des Sciences de l'Évolution (UM, CNRS, IRD, EPHE), c.c. 064, Université de Montpellier, Place Eugène Bataillon, 34095 \\ Montpellier cedex 05, France \\ Email:Rodolphe.Tabuce@univ-montp2.fr
}

\begin{abstract}
An unpublished mandible of the large hyracoid Titanohyrax andrewsi from the early Oligocene Jebel Qatrani Formation, Fayum Depression, Egypt is described. This specimen has a twofold importance. Firstly, it opens an unexpected window on early paleontological research in the Fayum because it was discovered as early as 1904 by the French paleontologist René Fourtau during an expedition to the Fayum organized by the Muséum National d'Histoire Naturelle, Paris (MNHN). This expedition has remarkably never been mentioned in the literature. Secondly, the mandible documents the best-preserved specimen of $T$. andrewsi, permitting a revision of one of the very rare Paleogene hyracoids. Interestingly, the new mandible was discovered two years before the first report of the species by Charles W. Andrews. The hypodigm of T. andrewsi is reviewed and the dentition as a whole is compared in detail, notably with other Titanohyrax species from the Fayum. The validity of the large Titanohyrax "schlosseri" species is discussed, but a pronounced sexual size dimorphism for T. andrewsi is favoured.
\end{abstract}

Keywords: Titanohyracidae, Oligocene, Afro-Arabia, Fayum

Submitted 1 December 2015, Accepted 15 March 2016

Published Online 18 April 2016, doi: 10.18563/pv.40.1.e4

(C) Copyright Rodolphe Tabuce April 2016

\section{INTRODUCTION}

The hyracoid Titanohyrax is one of the most iconic mammals from the African Paleogene fauna since Matsumoto (1922:844) described T. ultimus from the early Oligocene of the Jebel Qatrani Formation, Fayum Depression, Egypt, as an "extremely gigantic species, being the largest of all the hyracoids hitherto known". Body mass estimates for this species range from around $600 \mathrm{~kg}$ to more than $1300 \mathrm{~kg}$, close in weight to the extant Sumatran rhinoceros (Schwartz et al., 1995, but see Pickford 2015:204). The large size of T. ultimus evidently contrasts with the small sizes of the three living hyracoid genera whose body masses range from 1.3 to $5.5 \mathrm{~kg}$ (Shoshani et al., 2013). Besides T. ultimus, three other Titanohyrax species are known from the Jebel Qatrani Formation: T. angustidens Rasmussen \& Simons, 1988, T. andrewsi Matsumoto, 1922, and Titanohyrax nov. sp. (see Rasmussen \& Gutiérrez, 2010) (Fig. 1). These three species, although smaller than T. ultimus, are also part of the mammalian megafauna from the Fayum.

From the late early or early middle Eocene of Northwest Africa, two other Titanohyrax species are documented, $T$. mongereaui Sudre, 1979 from Glib Zegdou, Algeria and T. tantulus Court \& Hartenberger, 1992 from Chambi, Tunisia (Fig. 1). These two species were proposed to be the earliest representatives of the Titanohyrax lineage, but recently Barrow et al. (2010) questioned their generic attribution. These two Eocene species differ greatly by their sizes: T. tantulus from Chambi is putatively the smallest Titanohyrax species with a body mass estimated around $23 \mathrm{~kg}$ (Tabuce et al., in press), whereas T. mongereaui from Glib Zegdou is estimated to have weighed about $675 \mathrm{~kg}$ (Schwartz et al., 1995), and is thus the largest African terrestrial mammal from the early Paleogene period. In addition to T. mongereaui, two other very large, as yet undescribed, ?Titanohyrax species are known from the Glib Zegdou Formation (Tabuce et al., 2011) (Fig. 1). Besides its size and relatively high specific diversity, the genus Titanohyrax is peculiar among the numerous Paleogene hyracoids by its lophoselenodont dental pattern, fully molariform premolars, and relatively high-crowned cheek teeth (with the exception of $T$. mongereaui). This morphology, which is also characteristic of Antilohyrax - another titanohyracid from the Fayum - , is indicative of a probable folivorous diet (Rasmussen, 1989).

Despite their apparent central role in the Paleogene mammalian communities, the various Titanohyrax species are still poorly known due to their rarity in the fossil record. It is worth mentioning here that $T$. mongereaui is only documented by its holotype despite recent intensive field research in the Glib Zegdou area during the years 2003 to 2011 by the joint Montpellier/Tlemcen/Oran Universities fieldwork (Tabuce et al., 2011). Likewise, T. ultimus, initially described by Matsumoto (1922) based on four heavily worn and isolated teeth, has never been rediscovered in the Fayum during the productive joint Duke University/Egyptian Geological Museum fieldwork (1977 to present). As for T. angustidens and $T$. andrewsi, only eight and five specimens, respectively, have been described and recognized according to Rasmussen \& Simons (1988). Among these rare specimens, Rasmussen \& Gutiérrez (2010) recently reattributed, without any comment, a maxilla and a mandible of $T$. angustidens to $T$. andrewsi, thereby confusing the systematics of Titanohyrax, a genus with an already long and complicated systematic history.

The unexpected recent recognition of a well-preserved mandible of Titanohyrax andrewsi (MNHN-F-LBE 694) (Figs. 2-3) in the collections of the Muséum National d'Histoire Naturelle in Paris offers a unique opportunity to better document and review a very rare species from the Fayum. Moreover, this 
specimen which was discovered by the French geologist and paleontologist René Fourtau as early as March-April 1904 i.e. two years before the primary description of the two first Titanohyrax specimens by Andrews (1906) — opens a window on early research in the Fayum.

\section{Abbreviations. \\ AMNH: American Museum of Natural History, New York, USA \\ CGM: Egyptian Geological Museum, Cairo, Egypt \\ DPC: Duke Lemur Center Division of Fossil Primates, Durham, North Carolina, USA \\ FFZ: Fayum Faunal Zone (Rasmussen et al., 1992) \\ NHMUK: Natural History Museum, Department of Palaeon- tology, London, UK \\ MNHN: Muséum National d'Histoire Naturelle, Paris, France SMNS: Staatliches Museum für Naturkunde Stuttgart, Germany YPM: Peabody Museum of Natural History, Yale University, New Haven, Connecticut, USA \\ HYRACOIDS FROM THE FAYUM, CHRONOLOGY OF EARLY RESEARCH WITH SPECIAL REFERENCE TO TITANOHYRAX AND MNHN-F-LBE 694}

\section{Summary of early research}

In 1898, the British geologist Hugh J. L. Beadnell from the Egyptian Geological Survey in Cairo, who explored and mapped the eastern and northern border areas of the Fayum Depression, discovered numerous vertebrate remains north of the lake Birket Qarun. In April 1901, he was joined by the paleontologist Charles W. Andrews from the British Museum of Natural History for fieldwork in this area. Rapidly, they found land mammals in the Qasr el Sagha Series but also at a point higher in the escarpment, in the Fluvio-Marine Series also called Jebel el Qatrani beds (Beadnell, 1901, 1905).

Among the numerous specimens discovered by Andrews and Beadnell in the Jebel el Qatrani beds, the maxilla CGM 8635 was recognized as a member of the Hyracoidea and named Saghatherium antiquum, in reference to the ancient Qasr el Sagha temple situated on the northern shore of Birket Qarun (Andrews \& Beadnell, 1902). Saghatherium antiquum was the first hyracoid known from the Paleogene and the second fossil hyracoid documented, after Pliohyrax graecus (Gaudry, 1862) from the European late Miocene, only recognized as a hyracoid by Osborn (1899). In addition to $S$. antiquum, Andrews \& Beadnell (1902) also described but did not figure Saghatherium "minus" (now $S$. antiquum) based on the maxilla CGM 10011, later recognized as bearing DP1-4 instead of P4-M3 (Matsumoto, 1926). Andrews \& Beadnell (1902) also figured the premaxilla CGM 10009 which they attributed to the proboscidean Phiomia ?serridens. Only one year later, Andrews (1903) recognized the hyracoid affinity of this specimen while describing Megalohyrax eocaenus based on the premaxilla/ maxilla NHMUK M8502.

In 1904, Andrews published two other papers dedicated to new hyracoids from the Fayum. In April, based on the fragmentary mandibles CGM 8634 and NHMUK M8435, he described respectively Geniohyus mirus and "G." fajumensis (now Bunohyrax fajumensis) (Andrews, 1904a; NHMUK M8435 was figured in Andrews, 1906). One month later,
Andrews (1904b) described but did not figure Megalohyrax "minor" based on the maxilla CGM 8818 (figured in Andrews, 1906) now attributed to Megalohyrax eocaenus. He also described Saghatherium "magnum" (now Geniohyus magnus) based on the maxilla NHMUK M8398, and "Geniohyus" major (now Bunohyrax major) based on the three associated lower premolars CGM 8980 (figured in Andrews, 1906). At that time, Andrews referred Geniohyus to the Suidae.

Subsequent to this series of short papers, Andrews (1906) published additional hyracoid fossils in his comprehensive 'Descriptive Catalogue of the Tertiary Vertebrata of the Fayûm, Egypt'. He figured several specimens already described (see above), but also the mandible CGM 8822-3 which he attributed to his small species Megalohyrax "minor". He also attributed to this species the mandible NHMUK M9220. These two specimens were later attributed to the new genus and species Titanohyrax andrewsi by Matsumoto (1922), CGM 8822-3 being the holotype (Figs. 4-5).

After a last expedition in the Fayum in the spring of 1906, Andrews (1907) figured the mandible NHMUK M9480 attributed to Saghatherium "magnum" (now the holotype of Thyrohyrax pygmaeus) and he suggested that Geniohyus mirus (NHMUK M9485) may have some relationships with hyracoids instead of suids, a suggestion which is now fully accepted. Among the specimens discovered in 1906, Andrews also cited an enormous canine that he tentatively attributed to the creodont Pterodon africanus. Based on data listed on the NHMUK accession register, this canine is possibly

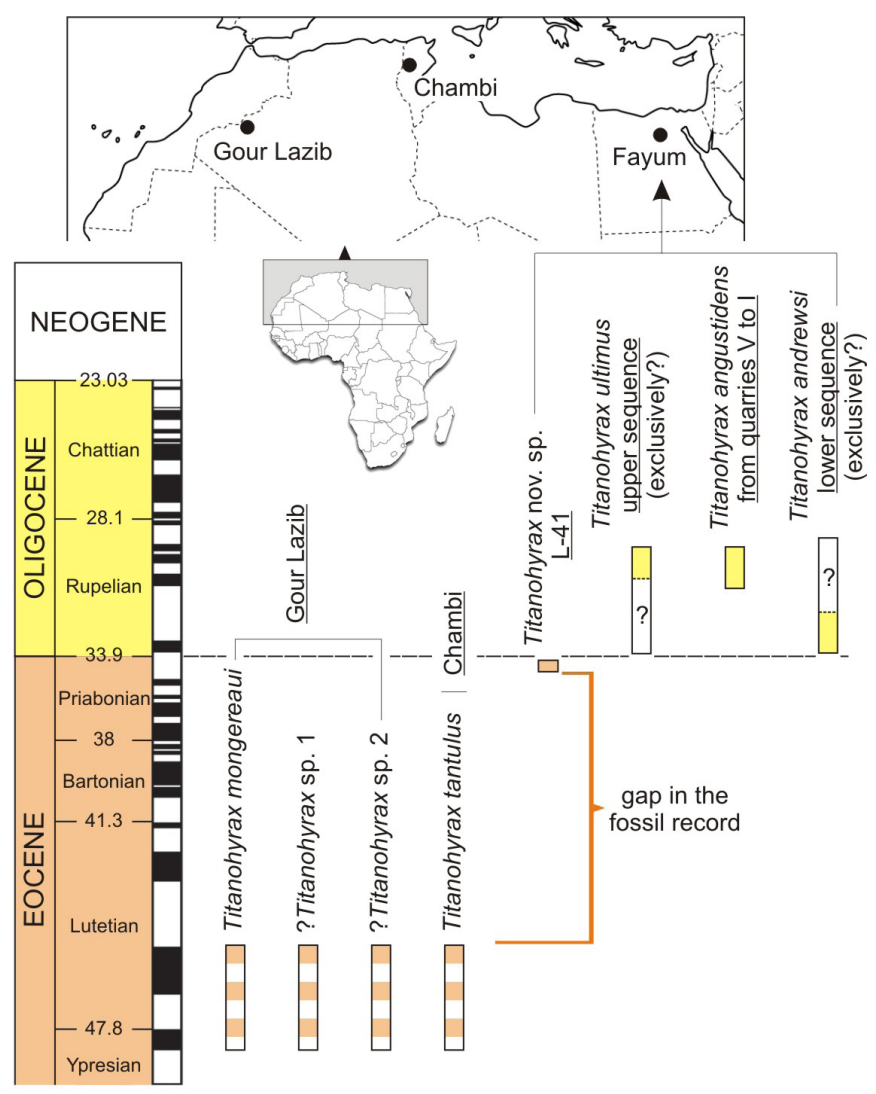

Figure 1. Temporal and geographic distribution of Titanohyrax species. Dashed blocks highlight the poorly-constrained dating (late early or early middle Eocene) for Gour Lazib and Chambi localities. Note also the uncertainties regarding the stratigraphic range of Titanohyrax ultimus and T. andrewsi (see text for discussion). 
NHMUK M9479, a specimen later included in the hypodigm of Titanohyrax ultimus by Matsumoto (1922). Surprisingly, all the three other specimens attributed to T. ultimus, although already recorded in the NHMUK accession register in 1904, were neither described nor mentioned by Andrews.

After Andrews' last contribution to the Fayum fauna was published, the British Museum of Natural History continued to acquire, at least until 1911, other hyracoid specimens from the Fayum from the German fossil dealer Friedrich Krantz, who purchased these fossils from the famous private collector Richard Markgraf.

Richard Markgraf, a Bohemian expatriate, worked principally in the Fayum from 1903 to 1916, where he collected Eocene and Oligocene vertebrates for several museums (Schmidt, 2009; Gingerich, 2014). He first arrived in the Fayum in November 1903 while he was engaged on a three-month expedition by Ernst Stromer from the Königlich Bayerischen Akademie der Wissenschaften in Munich. Since 1897, Markgraf collected marine Eocene vertebrates in the stone quarries of Gebel Mokattam for Eberhard Fraas from the Königlichen Naturalien-Cabinet in Stuttgart. During Stromer's expedition, some vertebrates were collected north of Birket Qarun, near the British localities (Stromer, 1907). After the end of the field expedition, Markgraf continued to live in the Fayum, in the small village of Senoures, and collected mammals, especially for E. Fraas. In 1905, he notably discovered the juvenile maxilla SMNS 11579 of Saghatherium antiquum described by Osborn (1906). Later, in 1907, when the American Museum of Natural History organized a collecting expedition to the Fayum, Markgraf was engaged in parallel to his work for E. Fraas (Morgan \& Lucas, 2002). After that, and until his death

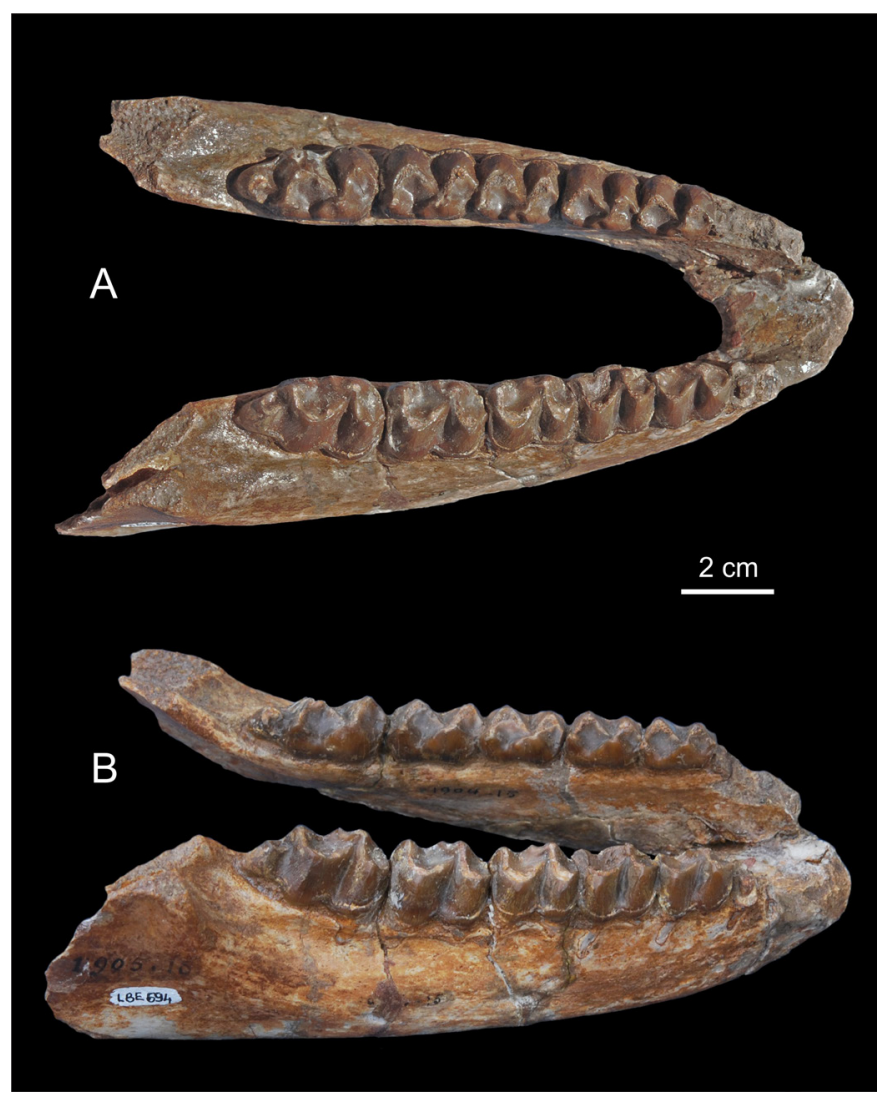

Figure 2. Titanohyrax andrewsi MNHN-F-LBE 694, left and right p3-m3; in occlusal (A) and lateral (B) views. in 1916, Markgraf continued to provide many institutions with Fayum mammals.

The hyracoids discovered by Markgraf between 1903 and 1916, including those he discovered during the 1907 AMNH expedition, have been the source of two principal monographs (Schlosser, 1911; Matsumoto, 1926). For a long time, these studies along with Andrews' (1906) monograph, provided all available data for Paleogene hyracoids. It was only during and after the 1970's that our knowledge progressed with the works of Meyer (1978), Sudre (1979), and Rasmussen \& Simons (1988). As for Titanohyrax, Markgraf collected for instance the best-preserved specimens of Titanohyrax angustidens ever found (the maxillae AMNH 14470 and SMNS 43921 and the mandibles AMNH 14555 and SMNS 43922). He also found SMNS 43941 which represents the only currently known maxilla of Titanohyrax andrewsi. In fact, excluding the rare DPC specimens published by Rasmussen \& Simons (1988) and the few NHMUK specimens, Markgraf found all the published Oligocene specimens documenting Titanohyrax.

Based on these specimens, Schlosser (1911) - like Andrews (1906) before him - failed to recognize the genus Titanohyrax as distinct; all specimens were treated as belonging to Megalohyrax. In addition to Andrews' Megalohyrax species (i.e., M. "minor" and M. eocaenus), he created M. "palaeotherioides" for the high-crowned specimens SMNS 43922 and SMNS 43921. Matsumoto (1922) partially clarified the problem by creating the new genus Titanohyrax. He listed four species: T. "palaeotherioides" (Schlosser's Megalohyrax palaeotherioides), T. andrewsi (including the lower dentition of Andrews' Megalohyrax minor), Titanohyrax ultimus, and T. "schlosseri" (Schlosser's Megalohyrax eocaenus specimens). Later, Meyer (1978) synonymized T. "palaeotherioides" and T. "schlosseri" within $T$. andrewsi judging that there are no morphological or metrical differences between these three species. Finally, Rasmussen \& Simons (1988) considered that Matsumoto's $T$. palaeotherioides is morphologically distinct from T. andrewsi; they thus erected the new species T. angustidens.

Titanohyrax has therefore a long taxonomic history that started in 1906 with the description of the two mandibles CGM 8822-3 and NHMUK M9220. It is thus astonishing that, two years before, when the MNHN acquired the well-preserved specimen MNHN-F-LBE 694, here attributed to Titanohyrax andrewsi, no paleontologist has paid attention to this specimen. This is all the more surprising because at that time "among recent discoveries in palaeontology, none have excited more interest than the Lower Tertiary vertebrate faunas of the Fayum" (Smith Woodward in Andrews, 1906).

The 1904 forgotten MNHN Expedition to the Fayum and the discovery of MNHN-F-LBE 694

Based on the MNHN accession register, MNHN-F-LBE 694 was discovered in 1904 by René Fourtau along with twenty-nine other mammalian specimens (including Palaeomastodon and Arsinoitherium) during excavations carried out in the Fayum. René Fourtau, who lived in Egypt beginning in 1888, was a French civil engineer associated with the Egyptian railway administration. Early he became interested in the problems of Egyptian geology and paleontology (Hume, 1921). As a member of the Institut Egyptien and later of the Geological Survey of Egypt, he published a series of papers dealing with invertebrates, notably echinoids, from the Eocene of Egypt (e.g., Fourtau, 1913). He received the 1903 Prix Savigny from the French Académie des Sciences (anatomy and 
zoology section) for his extensive contributions to knowledge of both fossil and extinct echinoids of Egypt. Fourtau also published the first treatise on the Miocene Moghara vertebrate fauna (Fourtau, 1918), and possibly collected an archaeocete rostrum from the Eocene of Egypt (Gingerich, 1991).

Institutional archives of the MNHN, consisting of correspondence and personal papers of Marcellin Boule and Albert Gaudry (consulted in March 2016), revealed that in March-April 1904, after he was named correspondent of the MNHN, Fourtau organized an expedition to the Fayum at the instance of M. Boule, professor and chair of paleontology at the MNHN. A two-week expedition received funding support from Edmond de Rothschild. Despite suitable results, this 1904 MNHN expedition to the Fayum has remarkably never been mentioned in the literature. Fortunately, the MNHN archives illuminate with details this expedition (Tabuce, Delmer and Tassy, in prep). For instance, on the $10^{\text {th }}$ April 1904, back to Cairo, Fourtau sent a letter to Boule in which he mentioned having found "une machoire inférieure à peu près complète, d'une espèce voisine des suiliens qui constitue au dire d'Andrews un genre nouveau" [an almost complete lower jaw of a species related to suillines which constitutes according to Andrews a new genus]; Fourtau added "le Geological Survey of Egypt ne possède qu'un coté de la machoire" [the Geological Survey of Egypt has only one side of the lower jaw]. There is no doubt that Fourtau is referring here to MNHN-F-LBE 694 and that he wrongly attributed this specimen to Geniohyus mirus which was described - as a suid - by Andrews in April 1904 based on the mandible CGM 8634 (see above).

\section{SYSTEMATIC PALEONTOLOGY}

Class Mammalia Linnaeus, 1758

Order Hyracoidea Huxley, 1869

Family Titanohyracidae Matsumoto, 1926

Genus Titanohyrax Matsumoto, 1922

Titanohyrax andrewsi Matsumoto, 1922

Holotype. CGM 8822-3, a partial mandible with left i1-2, $\mathrm{p} 3-\mathrm{m} 2$ and right $\mathrm{p} 2-\mathrm{m} 3$. The right $\mathrm{p} 2$ was complete at the time of Andrews's publication (cast NHMUK M8871) but is now broken.
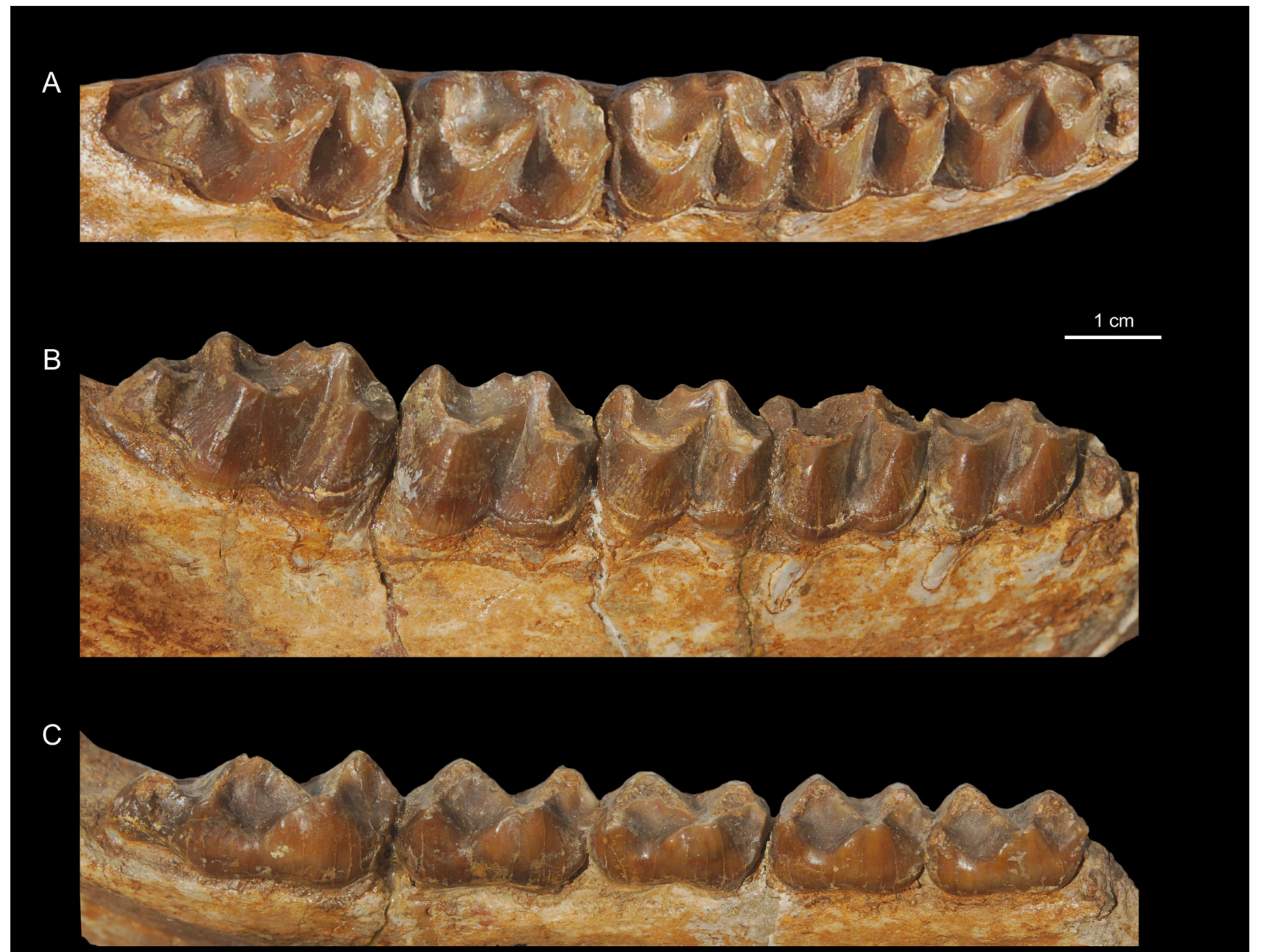

Figure 3. Titanohyrax andrewsi MNHN-F-LBE 694, right p3-m3; in occlusal (A) buccal (B) and lingual (C) views. 
Type locality. Unspecified locality in the "Fluvio-Marine beds" north of Birket Qarun (Andrews, 1906:97). Hypodigm. The holotype; NHMUK M9220, a partial left hemi-mandible with fragmentary p3-m3; MNHN-F-LBE 694, a mandible with well-preserved left and right p3-m3; SMNS $12626 \mathrm{~b}$, two poorly preserved hemi-mandibles with right and left fragmentary p1-m3; SMNS 43941, a left maxilla with worn P2-M2.

Range and distribution. Early Oligocene, Jebel Qatrani Formation, Fayum Depression, northern Egypt.

Revised diagnosis. Differs from T. tantulus and T. mongereaui by much larger size and smaller size (respectively), higher crowned cheek teeth, more pronounced selenodonty with sharper parastyle and mesostyle, more centrally positioned paracone and metacone, shorter preprotocrista and prehypocrista and absence of a paraconular swelling in upper molars. It further differs from $T$. tantulus by the presence of a preentocristid on $\mathrm{m} 2$. Differs from T. ultimus in its much smaller size, higher crowned cheek teeth, wider than long upper premolars with very short postmetacrista and poorly defined metastyle. Differs from T. angustidens by the lack of mandibular fenestra, lower crowned cheek teeth, relatively broader and more robust lower molars, mesiodistally-compressed trigonids, mesoconid on cristid obliqua, smaller hypoconulid, presence of a preentocristid on $\mathrm{m} 2-3$, wider than long upper premolars with smaller styles on the ectoloph, and smaller mesostyle and metastyle on upper molars.

\section{New data on previously described hyracoid specimens collected by Richard Markgraf and a revision of the hypodigm of Titanohyrax andrewsi}

Since Meyer (1978), the premaxilla AMNH 13328 has been attributed to T. andrewsi. A survey of the AMNH collections reveals however that the original label associated with the specimen shows it was collected " $40 \mathrm{~m}$ below basalt, north west of Quarry A by Markgraf in 1907'. This locality information refers to the Widan El Faras Basalt which overlies the sediments of the Jebel Qatrani Formation; it implies that AMNH 13328 was collected by R. Markgraf in the upper sequence of the Jebel Qatrani Formation. It is worth remembering that early workers, with the exception of Markgraf, collected mammals almost exclusively in the lower sequence, probably near the Quarries A and B (Simons, 1995:204). As for Titanohyrax, the levels of the upper sequence have never yielded $T$. andrewsi but only T. angustidens at Quarries V, R, and I (= FFZ 3 and 4). This statement is based on the YPM and DPC collections. In contrast, all specimens belonging to $T$. andrewsi are presumed to be from the FFZ 2 of the lower sequence, but their exact localities are unknown (see also discussion p9-10). To conclude, the presumed provenance of the premaxilla AMNH 13328 precludes its attribution to $T$. andrewsi and favours its attribution to $T$. angustidens. In addition to this stratigraphic evidence, AMNH 13328 perfectly matches the morphology of SMNS 43921, a specimen which preserves the premaxilla and the maxilla of T. angustidens (Schlosser, 1911 Plate XI, fig.1). AMNH 13328 and SMNS 43921 share the I3 and I2 close together (their alveolar borders are separated by only 4 $\mathrm{mm})$ and the same short distance between I1 and I2 $(\sim 1 \mathrm{~cm})$. There is therefore little doubt that AMNH 13328 belongs to $T$. angustidens.

Another Titanohyrax specimen, curated in SMNS collections, deserves comment. This specimen, also collected by R. Markgraf, was figured and succinctly described by Schlosser (1911 Plate XI, fig.7) as bearing C-M2. Since Matsumoto (1922), this specimen has been attributed to $T$. andrewsi. However, a survey of the Stuttgart collections reveals that Schlosser's figure combines in fact two distinct specimens: SMNS 43941 (a left maxilla with P2-M2) and SMNS 47769 (a right premaxilla/maxilla fragment with I1, $\mathrm{C}$, and P1, plus the alveoli of I2-3). These specimens do not fit together; moreover if SMNS 43941 undoubtedly belongs to $T$. andrewsi (see below), the premaxilla/maxilla fragment SMNS 47769 is obviously distinct from Titanohyrax. On this specimen, the distance between the I1 and the canine is about $10 \mathrm{~cm}$, the I1 is separated from I 2 by a diastema of $3 \mathrm{~cm}$ length, the I 2 is separated from I 3 by a diastema of $1 \mathrm{~cm}$ length, and the canine is also separated from the $\mathrm{I} 3$ by a long diastema of $3 \mathrm{~cm}$. As a result, SMNS 47769 documents a taxon with a long rostrum, a morphology which is incompatible with Titanohyrax. Indeed all available specimens (SMNS 43921 and SMNS 43922 for T. angustidens; CGM 8822-3 for T. andrewsi) demonstrate that Titanohyrax had a short rostrum with very short diastemata. In contrast, the premaxilla/maxilla fragment SMNS 47769 figured by Schlosser (1911) evokes both in size and morphology a large male of Pachyhyrax crassidentatus (I1 with an equilateral triangular cross section, quadrate premolariform P1 with a well-individualized metacone and a short postprotocrista directed towards the incipient hypocone which is not isolated from the cingulum).

A last short comment is needed regarding the maxilla AMNH 14470 and the juvenile mandible AMNH 14555, also collected by R. Markgraf in 1908 and 1909, respectively. These specimens, traditionally included in the hypodigm of Titanohyrax angustidens since Rasmussen \& Simons (1988), were recently reattributed, without any specific comment, to $T$. andrewsi by Rasmussen \& Gutiérrez (2010). Considering that these two specimens are characterized by high-crowned cheek teeth, which is the main diagnostic trait of $T$. angustidens, there is no reason to accept the systematic revision proposed by Rasmussen \& Gutiérrez (2010); it seems that these authors simply made a typographical error, using the old synonymy list of Titanohyrax andrewsi sensu Meyer (1978).

\section{Description and Comparison}

As stated above, the unique specimen documenting the upper dentition of T. andrewsi is SMNS 43941, a left maxilla with worn P2-M2 (Fig. 6). Based on this specimen alone, comparisons with Titanohyrax species and other titanohyracids (Antilohyrax, Afrohyrax, and Rupestrohyrax) are limited. Upper premolars of T. andrewsi appear wider than long while those of T. angustidens, T. ultimus, Afrohyrax and Antilohyrax are more quadrate. Moreover, compared to these taxa, the P4 of $T$. andrewsi is much more mesiodistally compressed than P3, with a relative smaller hypocone. Titanohyrax andrewsi has a peculiar ectoloph on all its cheek teeth: the parastyle is more developed and buccally displaced compared to the mesostyle, the postmetacrista is short and the metastyle is poorly defined. In T. angustidens, T. ultimus, Antilohyrax and Rupestrohyrax the mesostyle and metastyle are larger; T. angustidens differs also by a more mesially projected parastyle. Finally, the degree of hypsodonty of $T$. andrewsi is intermediate between $T$. ultimus and T. angustidens. Putting aside these differences, $T$. andrewsi and T. angustidens share, from P2 to M2, a bulbous protocone with a short preprotocrista and an insignificant to absent postprotocrista; such a morphology of the protocone 
also characterizes the P4 and M2 of T. ultimus and Afrohyrax. Antilohyrax and Rupestrohyrax have also an insignificant to absent postprotocrista but a longer preprotocrista. In Rupestrohyrax, the protocone is conical instead of being bulbous. All titanohyracids share a small compressed hypocone in contrast to the large protocone. The molars of $T$. andrewsi, T. angustidens and T. ultimus differ from those of T. tantulus and T. mongereaui by their higher crowns, more pronounced selenodonty and centrally positioned paracone and metacone, sharp parastyle and mesostyle, shorter preprotocrista and prehypocrista, and by the absence of a paraconular swelling. As a result, several characters set apart the Oligocene species ( $T$. andrewsi, T. angustidens and T. ultimus) from the Eocene ones (T. tantulus and T. mongereaui).

As for the lower dentition, only two mandibles - the holotype (a mandible with left i1-2, p3-m2 and right p2-m3) and NHMUK M9220 (a mandible with fragmentary p3-m3) - have been described so far; only the holotype was figured (Andrews, 1906; Matsumoto, 1922). It illustrates an old individual with somewhat worn teeth (Fig. 5). NHMUK M9220 bears crushed and broken teeth (Fig. 4). Accordingly, the new mandible MNHN-F-LBE 694, which belongs to a young adult individual with unworn teeth, documents with more details the morphology of $T$. andrewsi (Fig. 3). This specimen reveals that T. andrewsi possesses an incipient mesoconid on lower molars which increases in size from $\mathrm{m} 1$ to $\mathrm{m} 3$, such a mesoconid is present in T. tantulus but absent in T. angustidens, Afrohyrax, Antilohyrax, and Rupestrohyrax. In addition, T. andrewsi as Antilohyrax and Afrohyrax - presents a small hypoconulid on m1-2 whereas this structure constitutes in T. angustidens (SMNS 43922 and CGM 42848) a larger and sharply defined spur, having a hook-like outline in occlusal view. The morphology of the hypoconulid in T. tantulus is intermediate in morphology between T. andrewsi and T. angustidens. As for T. ultimus, the unique known lower molar is too worn and distally damaged to determine whether the mesoconid is present and the hypoconulid is large and sharp. Besides, as Court \& Hartenberger (1992) proposed, MNHN-F-LBE 694 confirms that $T$. andrewsi differs from $T$. tantulus and T. angustidens in having a short preentocristid on $\mathrm{m} 2-3$. Such a preentocristid also occurs in some specimens of Afrohyrax. Furthermore, as indicated by Rasmussen \& Simons (1988), MNHN-F-LBE 694 confirms that $T$. andrewsi differs from $T$. angustidens by the lack of mandibular fenestra (see below) and in having relative shorter and larger lower molars (length/width of m1-2 less than 1.5) due to a mesio-distally compressed trigonid. However, contrary to previous opinions (Rasmussen \& Simons, 1988; Rasmussen \& Gutiérrez, 2010), T. andrewsi does not differ from $T$. angustidens on the basis of a heavy buccal cingulid; both species having indeed a similarly constructed buccal cingulid (see SMNS 43922 for T. angustidens). Finally, as other Titanohyrax species, T. andrewsi is characterized by a well-pronounced metastylid. This character distinguishes Titanohyrax from other titanohyracids.

As for the anterior dentition, Andrews (1906) suggested that only two pairs of lower incisors were present in T. andrewsi; this statement was surely based on the short distance $(2.3 \mathrm{~cm})$ between $i 2$ and the mesial root of p2. Meyer (1978) argued moreover that there is some question as to whether there is also enough room for a canine. MNHN-F-LBE 694 unfortunately does not preserve the anterior dentition nor the front of the dentary, but viewing the holotype in lateral view (Fig. 5B), I see no reason to exclude the possibility that $T$. andrewsi had, as all Paleogene hyracoids for which the anterior dentition is known, a third reduced, usually caniniform, i3 (compared to the large i1-2) and a small (one- or two-rooted) premolariform canine

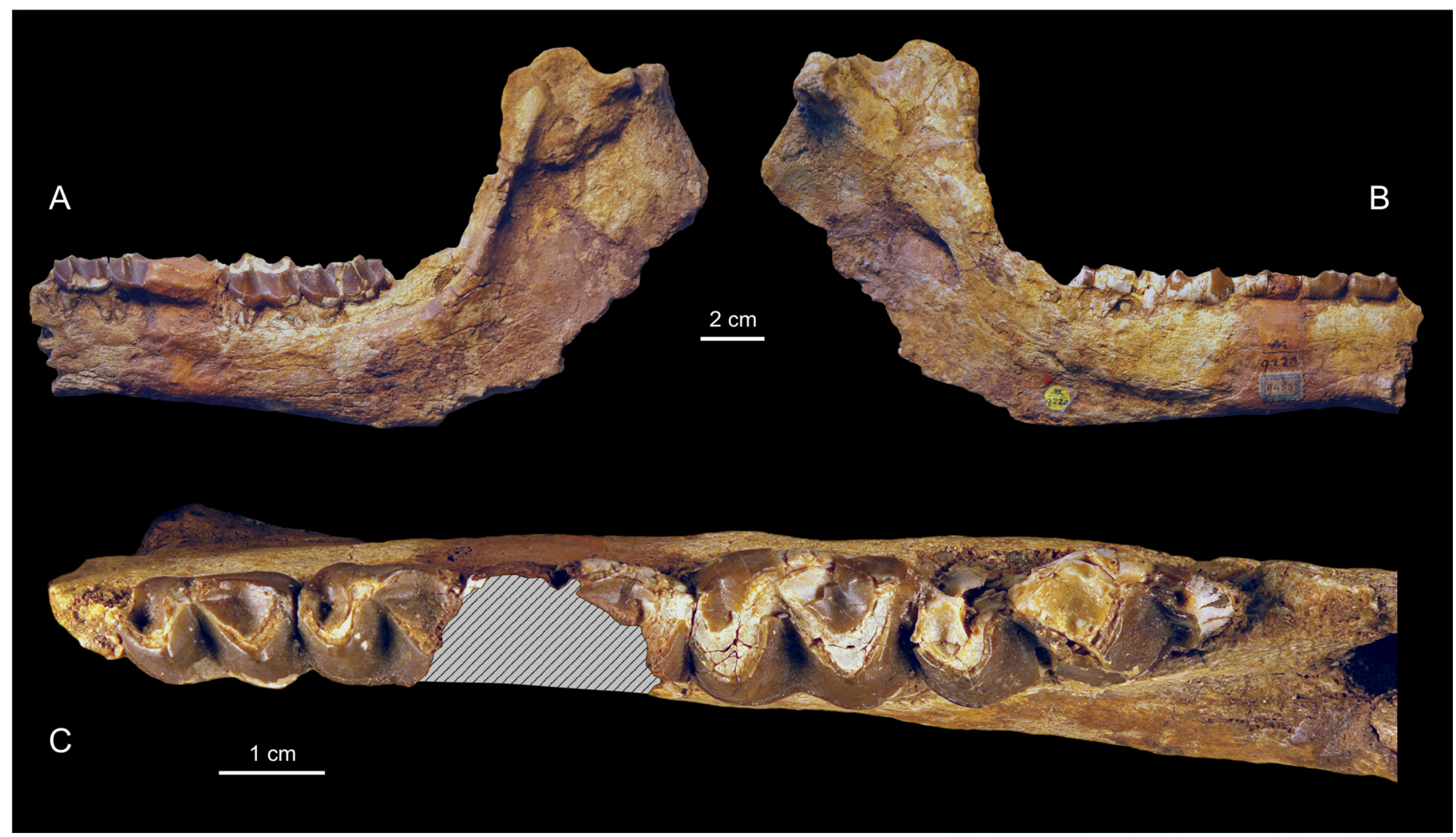

Figure 4. Titanohyrax andrewsi NHMUK M9220, left p3-m3; in buccal (A), lingual (B) and occlusal (C) views. 
in front of a larger two-rooted p1. Interestingly, T. andrewsi, T. angustidens and T. tantulus share broad and spatulate i1-2; whereas Antilohyrax developed mesiodistally elongated and hyperpectinate i1-2, and Afrohyrax shows the typical hyracoid condition (mesiodistally short i1-2 with slight pectinations at the apex) (Rasmussen \& Gutiérrez, 2010).

The mandibular corpus of MNHN-F-LBE 694 and of NHMUK M9220 are better preserved than that of the holotype. At the base of the ascending ramus, just behind $\mathrm{m} 3$, they show the typical hyracoid anterior opening of the coronoid canal. Besides, as in all Paleogene hyracoids for which the medial side of the ascending ramus is sufficiently preserved, the caudal foramen of the mandibular canal is visible as well as that of the coronoid canal situated just above it (Fig. 7A). Among living procaviids, some specimens of the genus Dendrohyrax also presents a very close position of the coronoid and mandibular caudal foramina, whereas Heterohyrax and Procavia usually have a coronoid caudal foramen more dorsally positioned on the ascending ramus. According to Andrews (1906), NHMUK M9220 presents an endocoronoid crest (Fig. 7B) similar to that of Procavia. Janis (1983) showed that Procavia exhibits a prominent boss on this crest for the tendinous insertion of the anterior deep temporalis. NHMUK M9220 presents no trace of this boss, showing instead a smooth (partially broken) en-

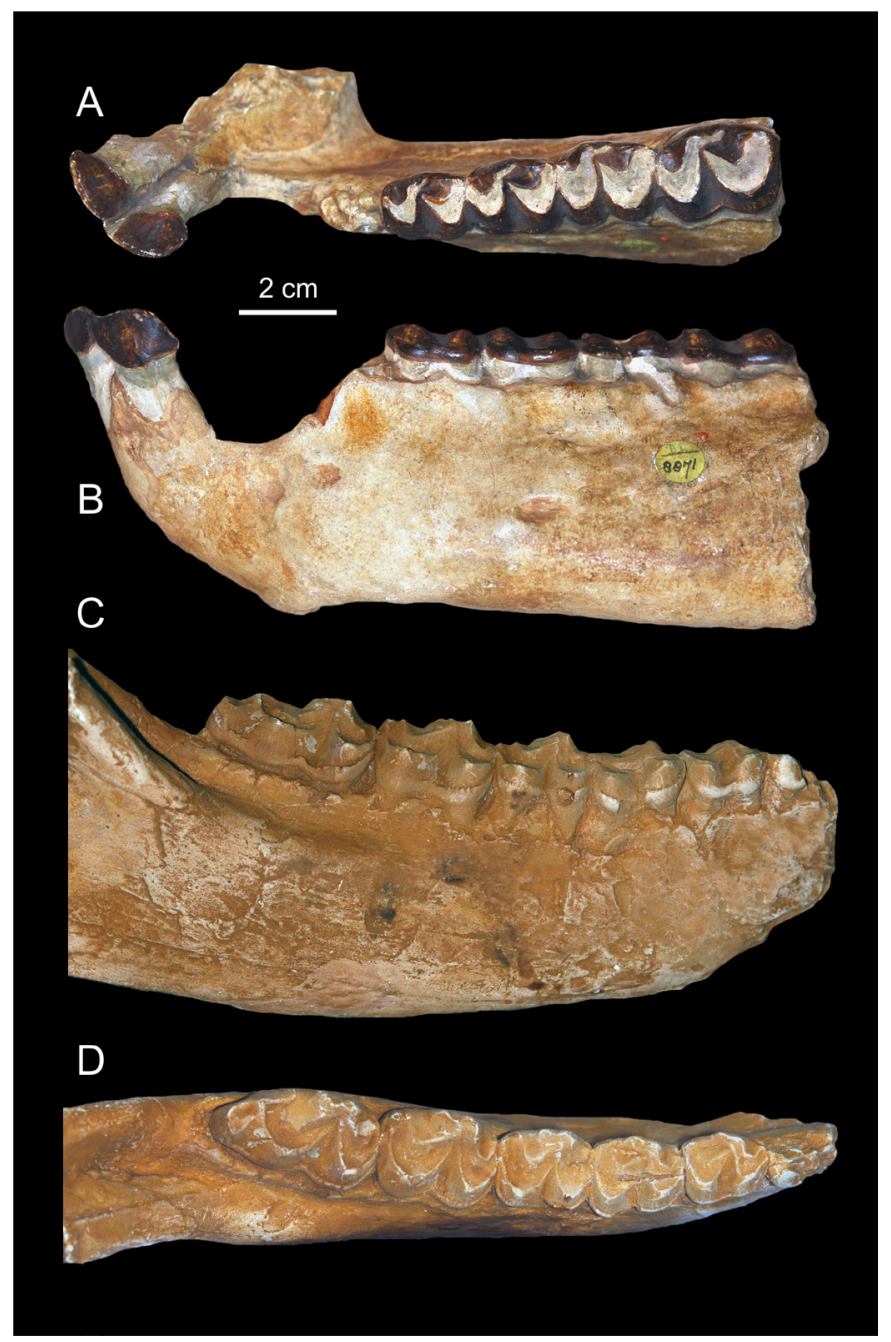

Figure 5. Titanohyrax andrewsi Holotype CGM 8822-3, left i1-2, p3-m2 in occlusal (A) and buccal (B) views (cast NHMUK M8871) and right p2-m3 in buccal (C) and occlusal (D) views (cast YPM 34807). docoronoid crest; the same is true for Titanohyrax angustidens (SMNS 43922). Bunohyrax fajumensis, Megalohyrax eocaenus, and Thyrohyrax pygmaeus are intermediate between the Titanohyrax and procaviid condition. In lateral view, the ascending ramus of NHMUK M9220 is almost at right angles to the horizontal ramus (Fig. 4) demonstrating that Titanohyrax andrewsi is distinct from procaviids in which the ascending ramus (including the coronoid process) is rostrally inclined. The vertical condition of the ascending ramus of $T$. andrewsi also characterizes the pliohyracids, Afrohyrax, and all other Paleogene hyracoids (with the exception of few specimens of Saghatherium bowni and Thyrohyrax meyeri in which the ascending ramus is rostrally inclined, E. Seiffert, pers. comm.).

The horizontal ramus of the holotype, NHMUK M9220, and MNHN-F-LBE 694 is massive but shallow. Its depth does not increase gradually and uniformly towards the rear (similarly to Titanohyrax angustidens, Antilohyrax, Seggeurius, and Microhyrax), contrasting with the morphology of most Paleogene hyracoids (Bunohyrax, Megalohyrax, Pachyhyrax, Saghatherium, and, to a lesser degree, Thyrohyrax), Afrohyrax, and modern hyracoids (pliohyracids and procaviids). On MNHN-F-LBE 694, two mental foramina are preserved, one medially positioned on the dentary under the roots of $\mathrm{p} 2$, the other more ventrally positioned under the roots of $\mathrm{m} 1$. On the holotype and NHMUK M9220, the posterior mental foramen is positioned under $\mathrm{p} 4$. Additionally, whereas the two hemi-mandibles of the holotype do not join because some fragments of bone in the front part of the symphyseal region are missing, MNHN-F-LBE 694 shows that T. andrewsi has a fused symphysis as in all hyracoids (Fig. 2). The symphysis, which extends back distally to the level of the posterior part of the $\mathrm{p} 2$, is deep, with the mesial ventral side steep. This peculiar morphology of the symphysis is similar in Titanohyrax angustidens and Antilohyrax, resembles Thyrohyrax, pliohyracids, and procaviids, but contrasts with the slender symphyses of Afrohyrax, Bunohyrax, Megalohyrax, Pachyhyrax, and Saghatherium. On MNHN-F-LBE 694 and NHMUK M9220,

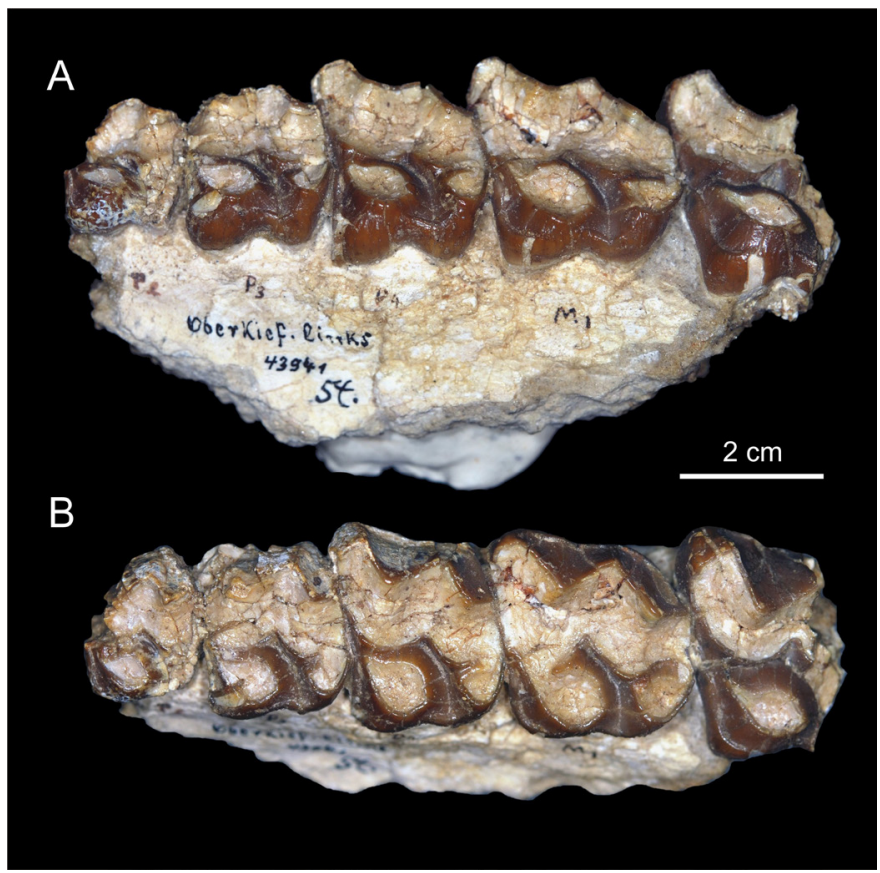

Figure 6. Titanohyrax andrewsi SMNS 43941, left P2-M2 in lingual (A) and occlusal (B) views. 
there are two large depressions corresponding to the pockets for the geniohyoid muscle on the ventral part of the symphysis. Afrohyrax presents the same character (Pickford 2009). This area is rarely preserved in Paleogene hyracoids. In Thyrohyrax, as in the extant procaviids, these insertions are slightly more internal and smaller; Bunohyrax (SMNS 43936) has no trace of these insertions.

In the Stuttgart collections, Schlosser (1911:105) briefly mentioned and measured but did not figure the two hemi-mandibles SNMN 12626b (Fig. 8). These specimens, which likely belong to one individual, were included by Matsumoto (1922) within his Titanohyrax "schlosseri", arguing that they are significantly larger than the two mandibles CGM 8822-3 and NHMUK M9220 that he referred to his T. andrewsi. When Meyer (1978) synonymized T. "schlosseri" and T. "andrewsi" sensu Matsumoto (1922), he unfortunately did not examine SNMN 12626b because all hyracoid specimens from the Stuttgart collections were thought lost, since they were packed up at the start of World War II (Meyer, 1978:288). Actually, the specimens were never lost. During the war, the Stuttgart collections were outsourced to a salt mine at Kochendorf, in monasteries away from Stuttgart, and in some other buildings outside Stuttgart (R. Ziegler, pers. comm.). In spite of the real interest of SNMN 12626b, these two hemi-mandibles were never figured nor discussed; it was only on the basis of the little data published by Schlosser (1911) that Meyer (1978) attributed them to $T$. andrewsi. Lastly, in their revision of Titanohyrax, it seems also that Rasmussen \& Simons (1988) paid no attention to SNMN 12626b. The attribution of SNMN $12626 \mathrm{~b}$ to Titanohyrax is justified by the occurrence of well-developed metastylids on the high-crowned premolars and molars (Fig. 8). Moreover, although detailed comparisons are impossible due to its fragmentary nature, SNMN 12626b is here attributed to $T$. andrewsi because of the presence of a small hypoconulid on m1-2 and the relative short and large lower molars (length/width of m1-2 smaller than 1.5) having a mesio-distally compressed trigonid.

\section{Size variability in Titanohyrax andrewsi: sexual dimorphism, trend toward increasing body size through the Fayum Oligocene sequences, or revival of Titanohyrax "schlosseri"?}

Despite the dental similarities between SNMN 12626b and other $T$. andrewsi specimens, it greatly differs from them by the height and robustness of the horizontal ramus (Fig. 8A-B). The height under $\mathrm{m} 2$ is near $8 \mathrm{~cm}$ in SNMN $12626 \mathrm{~b}$ whereas this value is only $4.2 \mathrm{~cm}$ in the holotype, $3.6 \mathrm{~cm}$ in NHMUK M9220, and $3.4 \mathrm{~cm}$ in MNHN-F-LBE 694. The angular region of SNMN 12626b is also very broad. The enlargement of this specimen is however certainly partially overestimated because of an important lateral compression and crushing.

The dental measurements of SNMN 12626b are 6-28\% larger than other specimens (depending on dental position), the holotype being intermediate in size between SMNS 12626b and MNHN-F-LBE 694 (Table 1). Despite these significant size differences in the lower dentition, the length of the premolars and molars of SNMN $12626 \mathrm{~b}$ perfectly matches those of the large maxilla SMNS 43941 discussed above. This suggests the existence of a possible bimodal distribution, due to sexual dimorphism, of dental and mandibular measurements within $T$. andrewsi: SMNS 12626b and SMNS 43941 (large specimens) may belong to males whereas the three other mandibles (small specimens), including the holotype, may document females.
Estimated using the ungulate regression equation for $\mathrm{m} 1$ area proposed by Legendre (1989), male and female body mass of T. andrewsi is estimated to have been around $430 \mathrm{~kg}$ and 240 $\mathrm{kg}$, respectively. As a result, the ratio male/female body mass of $T$. andrewsi, which reaches 1.79 , is strong by comparison with procaviids (1.11) and most extant ungulates, but similar to that of the African elephant (1.78), pholidotans (1.76) and American bison (1.63), and smaller than the nilgai (Boselaphus tragocamelus) (2) and the caribou (Rangifer tarandus) (2) (Owen-Smith, 1988; Lindenfors et al., 2007).

The hypothesis of pronounced sexual size dimorphism in $T$. andrewsi is supported by comparisons with some other hyracoids from the Fayum, and more particularly with Saghatherium species, which also present a large range of dental and mandibular sizes (Meyer, 1978; Rasmussen \& Simons, 1991). In Saghatherium antiquum for instance, molar sizes of males can be $10-15 \%$ larger than those of females. As in T. andrewsi, male mandibles of $S$. antiquum are remarkably deep and thick with very broad angular regions (Rasmussen \& Simons, 1991). The height of the mandible under $\mathrm{m} 2$, measured on three males (AMNH 13317, NHMUK M8879, and YPM 18105) and three females (NHMUK M8868a, YPM 18075, and SMNS 47774) of $S$. antiquum, has a mean of $3.9 \mathrm{~cm}$ and $2.2 \mathrm{~cm}$, respectively. The ratio between these values is thus similar to what is measured in $T$. andrewsi in which the height of the mandible under $\mathrm{m} 2$ is twice as high in males as in females. Living procaviids also present considerable cranial and dental size differences (e.g., Pickford, 2005), although they exhibit little or no size sexual dimorphism (Dunham \& Rudolf, 2009). According to Barrow et al. (2012), across a sample of 51 specimens of Procavia capensis and 17 specimens of Heterohyrax brucei, the largest specimens are $44 \%$ and $43 \%$ longer than the smallest (respectively) for the distance from the interincisal gap to the most distal point on M3 (these samples include different subspecies).

In addition to body size dimorphism, Paleogene hyracoids developed other patterns of sexual dimorphism. As in modern hyracoids, I1 are sexually dimorphic, with those of males being relatively longer, sharper, and more triangular in cross section than those of females (Fourie, 1983). Sexual dimorphism in the central lower incisors is also documented, with the enlargement of i2 in males. Accordingly, the similar size of i1 and i2 in

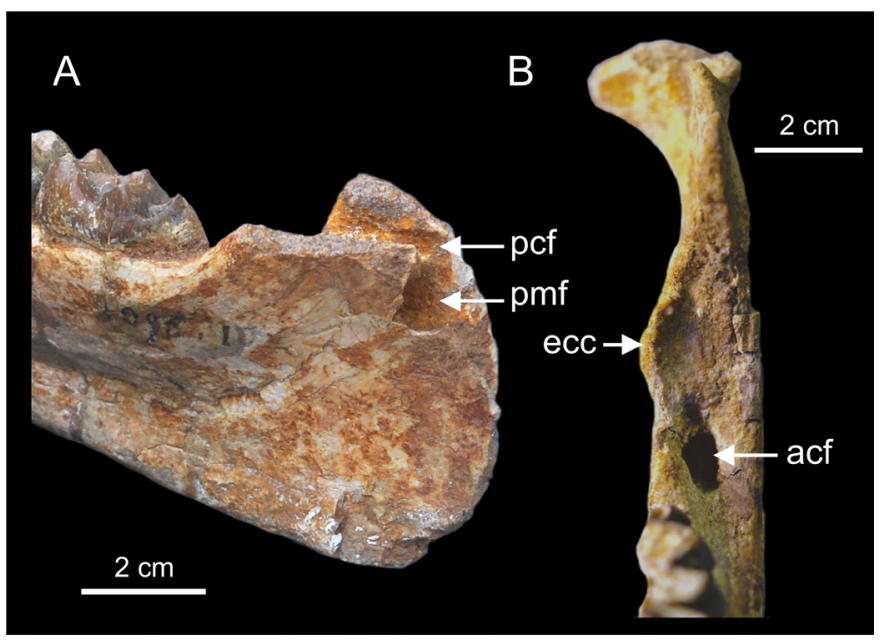

Figure 7. Titanohyrax andrewsi MNHN-F-LBE 694 (A) and NHMUK M9220 (B) showing details of the ascending ramus. Abbreviations: acf (anterior coronoid foramen); pcf (posterior coronoid foramen); ecc (endocoronoid crest); pmf (posterior mandibular foramen). 
NHMUK M9220 supports its atribution to a female.

The most striking sexually dimorphic trait within Paleogene hyracoids concerns the occurrence of an internal mandibular fenestra and chamber in many species; this structure possibly housed a laryngeal air sac that may have had a vocal function by acting as a resonating chamber (DeBlieux et al., 2006). In some species, the internal mandibular chamber is found exclusively in males (Thyrohyrax meyeri and Thyrohyrax domorictus). Other species (e.g., Thyrohyrax litholagus) show another pattern where an internal mandibular fenestra and inflated mandibular chamber occurs in males whereas females show the variable presence of an internal mandibular fossa or fenestra but lack an expanded chamber. Finally, some taxa (e.g., Pachyhyrax crassidentatus and Megalohyrax sp. from the quarry L-41 of the Fayum) have an internal mandibular fenestra in both sexes but with the greatest development of the mandibular chamber occurring in males (DeBlieux et al., 2006). In the titanohyracids Titanohyrax, Antilohyrax, and Afrohyrax, the internal mandibular fenestra and chamber also exhibit a variable pattern. In Afrohyrax, the fenestra and chamber are present in all adequately preserved mandibles, regardless of sex (Whitworth, 1954). In contrast, there is no fenestra and chamber in Antilohyrax pectidens in either sex (DeBlieux et al., 2006). As for Titanohyrax, no mandibles of $T$. tantulus, T. mongereaui, and T. ultimus are known. Concerning
T. angustidens, there are not enough mandibles to fully evaluate the dimorphism and variation of the mandibular fenestra. Finally, in T. andrewsi, the lack of mandibular fenestra in the larger mandible SMNS 12626b (presumably a male) as well as in the three smaller ones (presumably females) suggest that this species is similar to Antilohyrax pectidens in having no fenestra and chamber in either sex.

In addition to the here favoured sexual dimorphism hypothesis to explain the presence of both small and large specimens in $T$. andrewsi, another hypothesis involves the existence of two distinct species. This hypothesis would require the revival of Titanohyrax schlosseri Matsumoto, 1922 for the large maxilla SMNS 43941 and mandible SMNS 12626b. Besides its large size, Titanohyrax "schlosseri" would differ from $T$. andrewsi by only one character, a wider and longer third lobe on the $\mathrm{m} 3$ (Fig.8). This unique character often being variable within hyracoids, and mammals as a whole, it is here not considered enough to confirm the validity of $T$. "schlosseri". It is noteworthy, however, that Markgraf's collections held in Stuttgart include some other unique enigmatic specimens of unknown provenance such as the holotypes of the hyracoid "Mixohyrax niloticus" and of the primates Moeripithecus markgrafi, Propliopithecus haeckeli, and Parapithecus fraasi. Sadly we will probably never know where these specimens were recovered. Nevertheless, based on our current knowledge

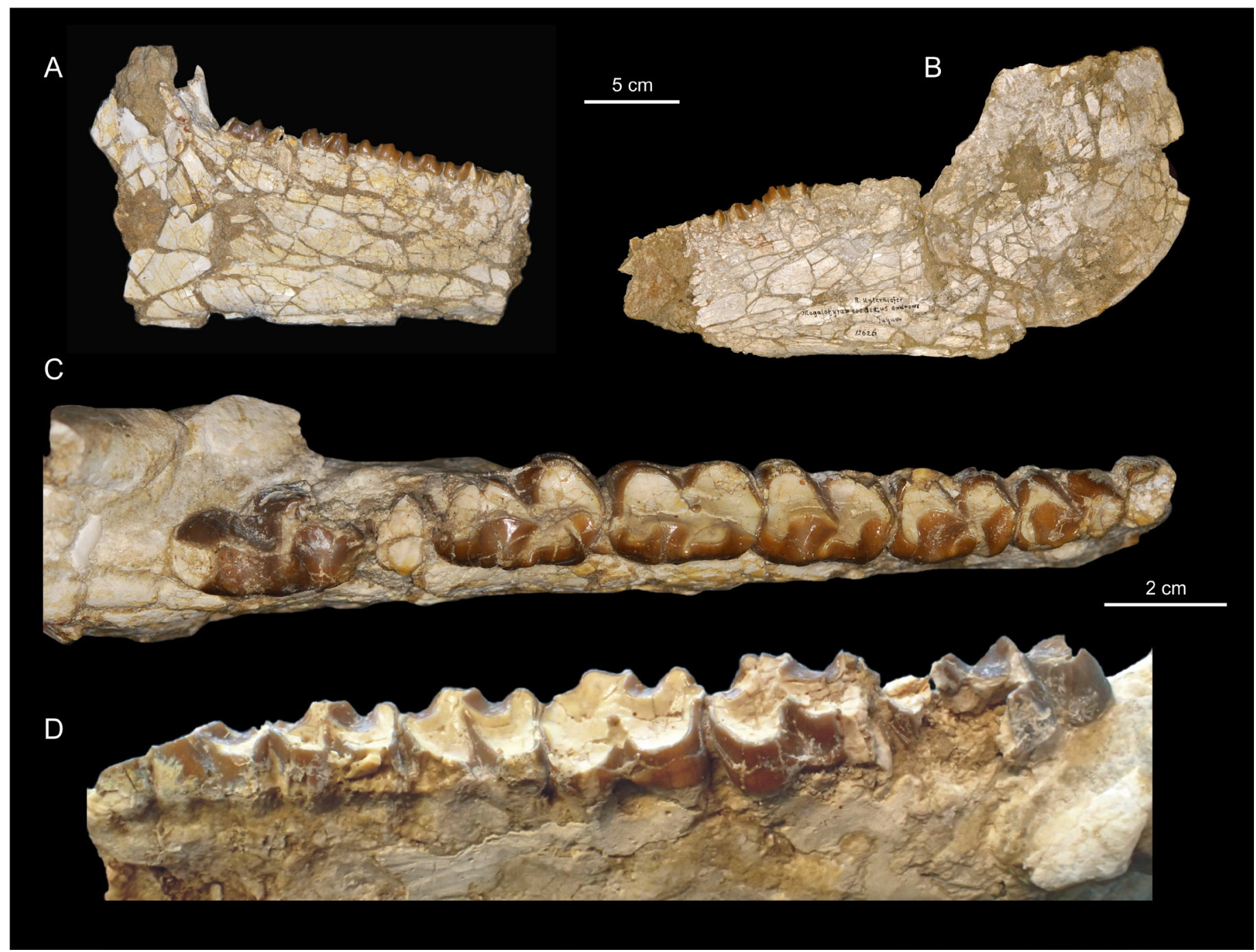

Figure 8. Titanohyrax andrewsi SMNS 12626b, left p1-m3 in lingual (A), occusal (C) and buccal (D) views, and right p1-m3 in lingual view (B). 


\begin{tabular}{|c|c|c|c|c|c|c|c|c|c|c|c|c|c|c|}
\hline & \multicolumn{2}{|c|}{ P1 } & \multicolumn{2}{|c|}{$\mathbf{P 2}$} & \multicolumn{2}{|c|}{ P3 } & \multicolumn{2}{|c|}{ P4 } & \multicolumn{2}{|c|}{ M1 } & \multicolumn{2}{|c|}{ M2 } & \multicolumn{2}{|c|}{ M3 } \\
\hline & $\mathbf{L}$ & W & $\mathbf{L}$ & W & $\mathbf{L}$ & W & $\mathbf{L}$ & W & $\mathbf{L}$ & W & $\mathbf{L}$ & W & $\mathbf{L}$ & W \\
\hline SMNS 43941 & & & $>16.7$ & $>21$ & 20 & $>23.8$ & 24.6 & 28.6 & 29.6 & 27.9 & $?$ & 33.3 & & \\
\hline
\end{tabular}

\begin{tabular}{|c|c|c|c|c|c|c|c|c|c|c|c|c|c|c|}
\hline & \multicolumn{2}{|c|}{ p1 } & \multicolumn{2}{|c|}{ p2 } & \multicolumn{2}{|c|}{ p3 } & \multicolumn{2}{|c|}{ p4 } & \multicolumn{2}{|c|}{ m1 } & \multicolumn{2}{|c|}{$\mathbf{m 2}$} & \multicolumn{2}{|c|}{ m3 } \\
\hline & $\mathbf{L}$ & W & $\mathbf{L}$ & W & $\mathbf{L}$ & $\mathbf{W}$ & $\mathbf{L}$ & $\mathbf{W}$ & $\mathbf{L}$ & W & $\mathbf{L}$ & $\mathbf{W}$ & $\mathbf{L}$ & $\mathbf{W}$ \\
\hline Holotype CGM 8822-3 (right) & & & 19.1 & 11.9 & 17.6 & 15.1 & 20 & 16.5 & 21 & 17.2 & 26.5 & 20.1 & 36 & 20 \\
\hline Holotype CGM 8822-3 (left) & & & & & 17.9 & 14.3 & 18.9 & 16.4 & 21.4 & 17.5 & 26.3 & 19.9 & & \\
\hline NHMUK M9220 & & & & & 16.5 & 12.5 & $?$ & 14 & ? & ? & 21 & 18 & $\approx 30$ & \\
\hline MNHN-F-LBE 694 (right) & & & & & 17 & 12.7 & 17.6 & 13.7 & 19.3 & 14.7 & 21.9 & 16.6 & 30.8 & 17.3 \\
\hline MNHN-F-LBE 694 (left) & & & & & 17.5 & 12.7 & 18.9 & 14.8 & 19.3 & 14.6 & 21.2 & 16.5 & 31.8 & 17.4 \\
\hline SMNS $12626 \mathrm{~b}$ (left) & & & 18.3 & 14.4 & 20.8 & 15.8 & 22.8 & 17.2 & 24.7 & 17.2 & 26.8 & 19.4 & 40 & ? \\
\hline SMNS $12626 \mathrm{~b}$ (right) & 16.4 & ? & 16.9 & ? & 20.9 & ? & 22.2 & 21 & 26.5 & 20 & 29 & ? & ? & ? \\
\hline
\end{tabular}

Table 1. Dental measurements (mm) of Titanohyrax andrewsi (L: lenght; W: width).

of the primate fossil record from the Fayum and of the phylogenetic relationships of early anthropoids (Seiffert et al., 2010; Seiffert, 2012), it is possible to envisage that Markgraf discovered these enigmatic primate specimens - and also hyracoids, including SMNS 43941 and SMNS 12626b - in levels stratigraphically situated between the Quarry E (FFZ 2) and the Barite Sandstone which marks the boundary between the lower and upper sequences of the Jebel Qatrani Formation. These levels, which constitute the upper part of the lower sequence, are represented by more than 50 meters of sediments (the "upper gravelly sandstone and upper red sandstone" of Bown \& Kraus, 1988). Since the 1960's, these levels have yielded rare vertebrate remains and few localities are known (Bown \& Kraus 1988:27).

As for the large Titanohyrax specimens (SMNS 43941 and SMNS 12626b), one cannot exclude another hypothesis that Markgraf recovered them very high in the upper sequence, in levels stratigraphically situated above the quarry $M$ (see the same conclusion for the premaxilla AMNH 13328 here attributed to $T$. angustidens). This possibility is supported by the recent discovery in the uppermost levels of the upper sequence of some anthracotheriid remains attributed to $\mathrm{Bo}$ thriogenys andrewsi (Sileem et al., 2015). Interestingly, until this discovery, the only reported specimens of Bothriogenys andrewsi - of unknown provenance - were also those collected by R. Markgraf, housed in the Stuttgart collections.

In light of all of this, it could be that SMNS 43941 and SMNS 12626 b really document a unique species (i.e., Titanohyrax "schlosseri") younger than T. andrewsi and intermediate in size between $T$. andrewsi and T. ultimus. If true, this implies that the upper dentition of T. andrewsi is unknown. Finally, one cannot exclude a final hypothesis that SMNS 43941 and SMNS 12626 b could illustrate - by their large size and possible provenance - a trend towards increasing body size within $T$. andrewsi through the Fayum Oligocene sequences. All these hypotheses are plausible but speculative and they can only be tested by the discovery of new large Oligocene specimens of Titanohyrax with a well-established stratigraphic provenance.

\section{CONCLUSION}

The discovery of a new specimen of Titanohyrax andrewsi is important as it yields evidence of the dental and mandibular morphology, not known so far from the few previously available specimens, thereby allowing a reassessment of the species. This revision is a first step towards a comprehensive revision of the genus Titanohyrax as several questions need to be resolved by further discoveries and/or analyses. Firstly, the alleged earliest Titanohyrax species, namely T. tantulus from Chambi T. mongereaui from Glib Zegdou and the two as yet undescribed ?Titanohyrax sp. from Gour Lazib, need to be reassessed considering that Barrow et al. (2010) argued that the available material for the two first species does not provide enough evidence to substantiate their attribution to the genus Titanohyrax. If true, this implies that the earliest Titanohyrax species is the yet undescribed species from the Late Eocene Fayum quarry L-41 (FFZ 1). The relationships of this species to the Oligocene Titanohyrax andrewsi, T. angustidens, and $T$. ultimus are also unresolved questions. Finally, the discovery in Afro-Arabia of new Middle to Late Eocene hyracoids would be crucial to test the hypothesis proposed by Barrow et al. (2010), that the radiation of Fayum hyracoids, including the Titanohyrax lineage, postdated the early Late Eocene (early Priabonian). In any case, the recent discovery of the new titanohyracid genus Rupestrohyrax from the Bartonian of Namibia (Pickford 2015) seems to suggest that the titanohyracid evolutionary history is more complex than previously thought.

\section{ACKNOWLEDGMENTS}

Thanks to G. Billet and P. Tassy (Muséum National d'Histoire Naturelle, Paris) for their help in arranging the analysis of the MNHN Titanohyrax material. I am very grateful to M.-A. Angel and P. Saussereau (Direction des Bibliothèques et de la Documentation, Muséum National d'Histoire Naturelle, Paris) who offered me access to the MNHN archives. I also thank P. Brewer (Natural History Museum, London), J. Galkin (American Museum of Natural History, New York), D. Brinkman (Yale Peabody Museum of Natural History, New Haven), G. Gunnell and C. Riddle (Division of Fossil Primates, Duke University, Durham), and R. Ziegler (Staatliches Museum für Naturkunde Stuttgart, Stuttgart) for access to collections. I thank S. Jiquel for technical assistance, C. Delmer, E. Buffetaut, P. Gingerich, and B. Tabuce for discussion or feedback on the manuscript, and E. Seiffert and M. Pickford for their helpful suggestions for improving the quality of this study.

\section{BIBLIOGRAPHY}

Andrews, C. W., 1903. Notes on an expedition to the Fayum, Egypt, with descriptions of some new mammals. Geological Magazine 4, 337-343.

Andrews, C. W., 1904a. Further notes on the mammals of the Eocene of Egypt, II. Geological Magazine 5, 157-162. 
Andrews, C. W., 1904b. Further notes on the mammals of the Eocene of Egypt, III. Geological Magazine 5, 211-215.

Andrews, C. W., 1906. A descriptive catalogue of the Tertiary Vertebrata of the Fayûm, Egypt, London.

Andrews, C. W., 1907. Notes on some vertebrate remains collected in the Fayum, Egypt. Geological Magazine 5, 97-100.

Andrews, C. W., Beadnell, H. J. L., 1902. A preliminary note on some new mammals from the upper Eocene of Egypt. Survey Department of Public Works Ministry, Cairo, 1-9.

Barrow, E. C., Seiffert, E. R., Simons, E. L., 2010. A primitive hyracoid (Mammalia, Paenungulata) from the early Priabonian (late Eocene) of Egypt. Journal of Systematic Palaeontology 8, 213-244. doi: 10.1080/14772010903450407

Barrow, E. C., Seiffert, E. R., Simons, E. L., 2012. Cranial morphology of Thyrohyrax domorictus (Mammalia, Hyracoidea) from the early Oligocene of Egypt. Journal of Vertebrate Paleontology 32, 166-179. doi: 10.1080/02724634.2012.635735

Beadnell, H. J. L., 1901. The Fayum depression: a preliminary notice of the geology of a district in Egypt containing a new Palaeogene vertebrate fauna. Geological Magazine 4, 540-546.

Beadnell, H. J. L., 1905. The topography and geology of the Fayum Province of Egypt. Survey Department of Egypt, Cairo.

Bown, T. M., Kraus, M. J., 1988. Geology and paleoenvironment of the Oligocene Jebel Qatrani Formation and adjacent rocks, Fayum Depression, Egypt. U.S. Geological Survey Professional Paper 1452, 1-60.

Court, N., Hartenberger, J.-L., 1992. A new species of the hyracoid mammal Titanohyrax from the Eocene of Tunisia. Palaeontology 35, 309-317.

DeBlieux, D. D., Baumrind, M. R., Simons, E. L., Chatrath, P. S., Meyer, G. E., Attia, Y. S., 2006. Sexual dimorphism of the internal mandibular chamber in Fayum Pliohyracidae (Mammalia). Journal of Vertebrate Paleontology 26, 160-169.

Dunham, A. E., Rudolf, V. H. W., 2009. Evolution of sexual size monomorphism: the influence of passive mate guarding. Journal of Evolutionary Biology 22, 1376-1386.

Fourie, L. J., 1983. The population dynamics of the rock hyrax, Procavia capensis (Pallas, 1766) in the Mountain Zebra National Park, PhD thesis Rhodes University.

Fourtau, R., 1913. Catalogue des invertébrés fossiles de l'Égypte représentés dans les collections du Geological Museum au Caire. 1ère partie. Echinides éocènes. Geological Survey of Egypt, Palaeontological series 1, 93.

Fourtau, R., 1918. Contribution à l'étude des vertébrés miocènes de l'Égypte. Geological Survey Department, Ministry of Finance, Egypt, Government Press, Cairo.

Gaudry, J. A., 1862. Animaux fossiles et géologie de l'Attique (18621867). In: Savy, F. (Ed.), Paris, pp. 215-218.

Gingerich, P. D., 1991. Provenance of Fourtau's Egyptian archaeocete. Investigations on Cetacea 23, 213-214.

Gingerich, P. D., 2014. Identification of basilosaurid archaeocetes (Mammalia, Cetacea) collected in Egypt by Richard Markgraf (1901-1916). Paläontologische Zeitschrift 88, 361-365. doi: 10.1007/s12542-013-0204-2

Hume, W. F., 1921. M. René Fourtau (Obituary). Geological Magazine $58,334-336$.

Janis, C. M., 1983. Muscles of the masticatory apparatus in two genera of hyraces (Procavia and Heterohyrax). Journal of Morphology 176, 61-87. doi : 10.1002/jmor.1051760106

Legendre, S., 1989. Les communautés de mammifères du Paléogène (Eocène supérieur et Oligocène) d'Europe occidentale : structures, milieux et évolution. Münchner Geowissenschaftliche Abhandlungen 16, 1-110.

Lindenfors, P., Gittleman, J. L., Jones, K. E., 2007. Sexual size dimorphism in mammals. In: Fairbairn, D.J., Blanckenhorn, W.U., Szekely, T. (Eds.), Sex, Size and Gender Roles: Evolutionary Studies of Sexual Size Dimorphism. Oxford University Press, Oxford, pp. 19-26. doi: 10.1093/ acprof:oso/9780199208784.001.0001

Matsumoto, H., 1922. Megalohyrax, Andrews and Titanohyrax, gen. nov. A revision of the genera of hyracoids from the Fayum,
Egypt. Proceedings of the Zoological Society 1921, 839-850. Matsumoto, H., 1926. Contribution to the knowledge of the fossil Hyracoidea of the Fayum, Egypt, with description of several new species. Bulletin of the American Museum of Natural History 56, 253-350.

Meyer, G. E., 1978. Hyracoidea. In: Maglio, V.J., Cooke, H.B.S. (Eds.), Evolution of African Mammals. Harvard University Press, Cambridge, pp. 284-314.

Morgan, V. L., Lucas, P., 2002. Notes from diary-Fayum trip, 1907. New Mexico Museum of Natural History and Science Bulletin $22,1-148$

Osborn, H. F., 1899. On Pliohyrax kruppii, Osborn, a fossil hyracoid, from Samos, Lower Pliocene, in the Stuttgart collection. A new type, and the first known Tertiary hyracoid. Proceedings of the 4th International Congress of Zoology, Cambridge, August 1898, 172-173.

Osborn, H. F., 1906. Milk dentition of the hyracoid Saghatherium from the upper Eocene of Egypt. Bulletin of the American Museum of Natural History 22, 263-266.

Owen-Smith, R. N., 1988. Megaherbivores. The influence of very large body size on ecology. Cambridge University Press.

Pickford, M., 2005. Fossil hyraxes (Hyracoidea: Mammalia) from the Late Miocene and Plio-Pleistocene of Africa, and the phylogeny of the Procaviidae. Palaeontologia Africana 41, 141-161.

Pickford, M., 2009. New Neogene hyracoid specimens from the PeriTethys region and East Africa. Paleontological Research 13, 265-278. doi: 10.2517/1342-8144-13.3.265

Pickford, M., 2015. New Titanohyracidae (Hyracoidea: Afrotheria) from the Late Eocene of Namibia. Communications of the Geological Survey of Namibia 16, 200-214.

Rasmussen, D. T., 1989. The evolution of the Hyracoidea: a review of the fossil evidence. In: Prothero, D.R., Schoch, R.M. (Eds.), The Evolution of Perissodactyls. Oxford University Press, New York, pp. 57-78.

Rasmussen, D. T., Simons, E. L., 1988. New Oligocene hyracoids from Egypt. Journal of Vertebrate Paleontology 8, 67-83. doi: $10.1080 / 02724634.1988 .10011684$

Rasmussen, D. T., Simons, E. L., 1991. The oldest Egyptian hyracoids (Mammalia: Pliohyracidae): new species of Saghatherium and Thyrohyrax from the Fayum. Neues Jahrbuch für Geologie und Paläontologie 182, 187-209.

Rasmussen, D. T., Bown, T. M., Simons, E. L., 1992. The EoceneOligocene transition in continental Africa. In: Prothero, D.R., Berggren, W.A. (Eds.), Eocene-Oligocene Climatic and Biotic Evolution. Princeton University Press, Princeton, pp. 548-566.

Rasmussen, D. T., Gutiérrez, M., 2010. Hyracoidea. In: Sanders, W.J., Werdelin, L. (Eds.), Cenozoic Mammals of Africa. University of California Press, Berkeley, pp. 123-145.

Schlosser, M., 1911. Beiträge zur Kenntnis der oligozänen Landsäugetiere aus dem Fayum, Ägypten. Beiträge zur Paläontologie und Geologie Österreich-Ungarns 24, 51-167.

Schmidt, I., 2009. Richard Markgraf: Fossiliensammler. Austria, 1-96. Available at: http://www.kritzkratz.net/markgraf/Markgraf Buch-20090101 kl.pdf

Schwartz, G. T., Rasmussen, D. T., Smith, R. J., 1995. Body-size diversity and community structure of fossil hyracoids. Journal of Mammalogy 76, 1088-1099. doi: 10.2307/1382601

Sileem, A. H., Sallam, H. M., Hewaidy, A. G. A., Gunnell, G. F., Miller, E. R., 2015. Anthracotheres (Mammalia, Artiodactyla) from the upper-most horizon of the Jebel Qatrani Formation, latest Early Oligocene, Fayum Depression, Egypt. Egyptian Journal of Paleontology 15, 1-11.

Seiffert, E. R., 2012. Early primate evolution in Afro-Arabia. Evolutionary Anthropology 21, 239-253. doi: 10.1002/ evan. 21335

Seiffert, E. R., Simons, E. L., Fleagle, J. G., Godinot, M., 2010. Paleogene anthropoids. In: Sanders, W.J., Werdelin, L. (Eds.), Cenozoic Mammals of Africa. University of California Press, Berkeley, pp. 369-391.

Shoshani, J., Bloomer, P., Seiffert, E. R., 2013. Family Procaviidae. 
In: Kingdon, J., Happold, D., Hoffmann, M., Butynski, T., Happold, M., Kalina, J. (Eds.), Mammals of Africa, Volume I: Introductory Chapters and Afrotheria. Bloomsbury Publishing, London, pp. 149-152.

Simons, E. L., 1995. Egyptian Oligocene primates: a review. Yearbook of Physical Anthropology 38, 199-238.

Stromer, E., 1907. Geologische Beobachtungen im Fajüm und am unteren Niltale in Ägypten. Abhandlungen der Senckenbergischen naturforschenden Gesellschaft, Frankfurt am Main 29, 138-147.

Sudre, J., 1979. Nouveaux mammifères éocènes du Sahara Occidental. Palaeovertebrata 9, 83-115.

Tabuce, R., Charruault, A.-L., Adaci, M., Bensalah, M., Ben Haj Ali, M., Essid, E. M., Marivaux, L., Vianey-Liaud, M., Mahboubi, M., 2011. The early Eocene radiation of Hyracoidea (Mammalia, Afrotheria): new fieldwork evidence from northwestern Africa. In: Lehmann, T., Schaal, S.F.K. (Eds.), The World at the Time of Messel. Senckenberg Research Institute and Natural History Museum Frankfurt, pp. 161-162.
Tabuce, R., Seiffert, E. R., Gheerbrant, E., Alloing-Séguier, L., Koenigswald, W. v., in press. Tooth enamel microstructure of living and extinct hyracoids reveals unique enamel types among mammals. Journal of Mammalian Evolution. doi: 10.1007/s10914-015-9317-6

Whitworth, T., 1954. The Miocene hyracoids of east Africa. Fossil Mammals of Africa 7, 1-58. 